\title{
Jackfruit Seeds Protein Isolate by Spray Drying Method: The Functional and Physicochemical Characteristics
}

\author{
M. Amdadul Haque ${ }^{*}$, Fatema Akter1, Habibur Rahman², M. A. Baqui ${ }^{3}$ \\ ${ }^{1}$ Department of Agro-Processing, Bangabandhu Sheikh Mujibur Rahman Agricultural University (BSMRAU), Gazipur, Bangladesh \\ ${ }^{2}$ Department of Entomology, BSMRAU, Gazipur, Bangladesh \\ ${ }^{3}$ Department of Civil Engineering, Uttara University, Dhaka, Bangladesh \\ Email: *mahaque@bsmrau.edu.bd, *amdad115@gmail.com
}

How to cite this paper: Haque, M.A., Akter, F., Rahman, H. and Baqui, M.A. (2020) Jackfruit Seeds Protein Isolate by Spray Drying Method: The Functional and Physicochemical Characteristics. Food and Nutrition Sciences, 11, 355-374.

https://doi.org/10.4236/fns.2020.115026

Received: April 11, 2020

Accepted: May 8, 2020

Published: May 11, 2020

Copyright $\odot 2020$ by author(s) and Scientific Research Publishing Inc. This work is licensed under the Creative Commons Attribution International License (CC BY 4.0).

http://creativecommons.org/licenses/by/4.0/

\begin{abstract}
With increased demand for plant based proteins by the consumers, the food manufacturers appeal for the new plant proteins with predetermined characteristics. This study aims at isolating the protein fraction from jackfruit seeds and characterizing the protein powder for functional and physicochemical properties. The protein part of the seeds was separated through $\mathrm{pH}$ treatments and centrifugation process and finally, the concentrate was converted into powder by spray drying method. The functional properties such as solubility, gelling capacity and emulsion properties and the physicochemical properties such as crystallinity, morphology and particle size distribution of the jackfruit seeds protein isolate (JSPI) were studied. The secondary structural elements of JSPI were also determined by Fourier-transform infrared (FTIR) spectroscopy. About $76.89 \%$ protein was estimated in the prepared JSPI with $78.44 \%$ solubility in an aquatic solvent. The least gelation concentration of JSPI was $12 \%$ in a salt solution. The $\mathrm{pH}$ of the solvent significantly affected the emulsifying and foaming properties. The protein isolate possessed amorphous structure, moderate bulk density and almost $75 \%$ of the particles fell in a similar size distribution range. The conformational study reported that the $\beta$-sheet is the dominant secondary structural element with the highest content of $50.28 \%$. The observed features suggest that the JSPI holds satisfactory functional and physicochemical characteristics for being used in protein-enriched foods.
\end{abstract}

\section{Keywords}

Protein Isolate, Spray Drying, Functional Properties, Physicochemical Properties, Protein Conformation 


\section{Introduction}

The demand for plant-derived proteins is continuously increasing for its' superior health benefits, easy digestibility and economic rationales [1]. As a consequence, isolation and characterization of cereal and bean proteins such as soy protein, flaxseed protein, and lentil protein have received good attention from the researchers [2] [3] [4]. In the journey of exploring plant proteins, recently, jackfruit seeds (JFSs) have been established as a good source of protein. The protein content of jackfruit seed flour was determined as $16.01 \%$ by [5] and $13.50 \%$ by $[6]$.

Jackfruit (Artocarpus heterophyllus Lam) belonging to the Moraceae family grows abundantly in south-east Asian countries such as Indonesia, Bangladesh, and India as well as in some areas of Brazil and Australia. Jackfruit is termed as the national fruit of Bangladesh. The annual production of this fruit is more than a million metric tons in Bangladesh, such as in the year 2015, about 1,031,316 metric tons of jackfruit was produced from 27,316 acres of land [7]. A single fruit may contain up to 500 juicy cells, each of them enclosing a seed; thus the whole seeds consist around $10 \%$ to $15 \%$ of a fruit weight. Traditionally, the majority of the seeds are discarded in the environment, although a little portion is consumed after minimal processing like roasting and boiling. These seeds can, however, be used as a good source of protein, if processed suitably. A significant contribution is possible in meeting the protein demand by using the JFSs protein fraction in food formulations. Understanding of functional and physicochemical properties of isolated and dried protein provides better insights of it hydrothermal behavior. Such information makes it convenient to use in new food formulation.

Isolated proteins are increasingly being used as an ingredient in preparation of the protein enriched foods. Prior information regarding the functional and physicochemical properties of an isolated protein helps to use it in new food formulation with minimum hassle. For better application as an ingredient, the proteins should ideally possess several desirable functional properties such as solubility, water holding capacity, gel formation ability and foaming capacity. These functional properties influence in determining the food characters during processing, storage, and consumption [8]. For example, the higher solubility of a protein increases the foaming and emulsion ability of protein, thus improves the food structure and enhances the digestibility of protein-enriched foods [9]. Knowledge of the emulsifying and foaming properties of proteins is necessary to evaluate their potential to use as food additives. Several molecular parameters such as $\mathrm{pH}$, ionic strength, and viscosity are essential determinants in the formation, stability, and textural properties of protein-fat-water emulsions [10]. The crystalline behavior of any food ingredient determines the critical characteristic of finished product. For example, the amorphous particles possess higher solubility and dispersibility in the solution than the crystalline particles [11]. Similarly, morphology of the particles has great influence on the handling, transportation 
and storage behavior of the finished product.

The secondary structure of protein plays a vital role in protein folding and unfolding process. The 3D structure of the protein, which is crucial for protein functionality, is attributed to compact and stable secondary structural elements such as $\alpha$-helix, $\beta$-sheet, and $\beta$-turn. These elements also play decisive roles in determining evolution, size, and geometry of protein [12]. Fourier Transform Infrared (FTIR) spectroscopy provides information about the secondary structure of proteins by chemical composition and physical state of the sample geometry [13]. The denaturation of protein is an inevitable structural change due to external stresses such as extreme high or low heat and extreme acidic or alkaline conditions. The denatured protein results in poor solubility and lacks in exerting appropriate functionalities [14]. Application of the numerical software for fitting the bands of the spectra can assess the stress exerted denaturation of protein [13] [15].

Various drying methods are used to dry the liquid slurry in the protein isolation process. Spray drying and freeze drying are by far the most popular methods for drying protein solutions [16]. Although the solid protein obtained from freeze drying has the advantage of storage stability, it is not a direct particle formation method. It requires a secondary procedure to break apart the cake into particles. Spray drying is the most common powder generating method, wherein a liquid feed is rapidly transformed into dried particles. Spray drying is a relatively inexpensive powder forming technology. This is about $1 / 9$ and $1 / 6$ times cheaper in terms of capital and operation costs, respectively, compared to freeze drying [17].

Few research initiatives are found in the literature regarding isolation of jackfruit seeds protein and its' characterization. They employed different methods for drying the isolated protein. The research groups [18] [19] observed the structural and functional properties of vacuum filtered and dried $\left(\right.$ at $\left.35^{\circ} \mathrm{C}\right)$ jackfruit seeds protein isolate (JSPI). Another group [20] used simple tray drying at $50^{\circ} \mathrm{C}$ for drying the protein concentrate. Few studies were devoted for physicochemical characterization and amino acid profile evaluation of freeze dried JSPI [5] [21]. However, despite possessing the highest probability of commercial convenience of the spray dried protein powder, no scientific study, so far, is reported on the preparation and functional characterization of JSPI using this dryer.

Therefore, this study aims at preparing jackfruit seeds protein isolate by spray drying method. The key functional and physicochemical properties of the powder protein were observed. The protein powder was also studied by infra-red spectroscopy to determine the secondary structural properties.

\section{Materials and Methods}

\subsection{Raw Materials}

Jackfruit (Artocarpus heterophyllus Lam.) seeds were collected from the local 
market of Narsingdi, Bangladesh. These were sun-dried for quick separation of the white outer layers. After cutting approximately $3 \times 5 \mathrm{~mm}$ size, the seed pieces were dried into a cabinet dryer to bring the moisture content within $10 \%$ $12 \%$. Finally, the seeds were ground and passed through a 75-micron sized sieve to get JFSs flour. The obtained powder was packed into airtight containers for further analyses.

\subsection{Preparation of Jackfruit Seeds Protein Isolate (JSPI)}

JSPI was prepared according to the method followed by [4] with slight modification. The seeds flour was suspended in distilled water $(1: 10 \mathrm{w} / \mathrm{v})$. The $\mathrm{pH}$ of the slurry was adjusted to 9.0 by using $1 \mathrm{M} \mathrm{NaOH}$ solution and kept in rest for one hour. The slurry was then centrifuged (at 12,600 g, for $15 \mathrm{~min}$ ). The supernatant protein solution was separated and adjusted to $\mathrm{pH} 4.5 \mathrm{using} 1 \mathrm{M} \mathrm{HCl}$. The solution was then stirred for $30 \mathrm{~min}$ at $400 \mathrm{rpm}$ and left undisturbed for cold precipitation overnight $\left(4^{\circ} \mathrm{C}\right)$. The supernatant was carefully siphoned off, and the obtained protein precipitate was collected by centrifugation at $2217 \mathrm{~g}$ for $15 \mathrm{~min}$. The accumulated protein was washed 3 - 4 times with distilled water to eliminate all soluble components. The protein was re-suspended $(10 \%, \mathrm{w} / \mathrm{v})$ in distilled water and the $\mathrm{pH}$ was set to 7.0. The protein solution was then dried using a spray dryer (Yamato ADL-311S) to get dry protein powder. The input temperature was $160^{\circ} \mathrm{C}$, the output temperature was $60^{\circ} \mathrm{C}$, and the nozzle air pressure was $0.2 \mathrm{MPa}$. The spray dried powder was then stored at room temperature in a glass bottle.

\subsection{Determination of Protein Content}

The protein content of JSPI was determined by the Micro-Kjeldahl method [22] using 6.25 as the protein conversion factor. One (1) g of protein powder was used for digestion, distillation, and titration following the standard protocols for Micro-Kjeldahl method. The average values from the replicated experiments were accepted.

\subsection{Determination of Functional Properties of JSPI}

\subsubsection{Protein Solubility}

The solubility of JSPI was determined according to the method used in [23] with slight modification. One (1) g of JSPI powder was diluted into $100 \mathrm{~mL}$ of distilled water. The suspension was mixed evenly through continuous stirring for 30 $\min$ at $500 \mathrm{rpm}$. The suspension was then kept in the refrigerator $\left(4^{\circ} \mathrm{C}\right)$ for overnight and centrifuged $(12,600 \mathrm{~g} / 20 \mathrm{~min})$. The soluble protein content in the supernatant was determined by the Micro-Kjeldahl method [22]. The protein solubility (PS) was estimated from the amount of protein found in the supernatant and the total sample used to prepare the solution following Equation Number 1 .

PS $(\%)=($ Percent of protein in the supernatant/Total JSPI in the solution $) \times 100(1)$ 


\subsubsection{Water Holding Capacity}

The water holding ability of JSPI was determined according to the method described in [24]. One (1) $\mathrm{g}$ of protein sample was suspended into $10 \mathrm{~mL}$ of distilled water in a $15 \mathrm{~mL}$ graduated conical centrifuge tube. The suspension was stirred evenly at $400 \mathrm{rpm}$ and allowed to stand at room temperature for $1 \mathrm{~h}$. It was then centrifuged at $2217 \mathrm{~g}$ for $30 \mathrm{~min}$, and the volume of the supernatant was measured. The water-holding capacity was expressed from the amount of water held by $1.0 \mathrm{~g}$ of protein sample.

\subsubsection{Oil Holding Capacity}

The oil holding capacity of JSPI was determined following a similar method for water holding capacity, where corn oil was used as a suspension medium instead of water.

\subsubsection{Bulk Density}

Five (5.0) g of JSPI was put into a $25 \mathrm{~mL}$ measuring cylinder. The initial weight and the initial volume of the sample were recorded. The JSPI powder was poured into a cylinder and tapped continuously until a constant level was obtained. Again, the weight and volume of the sample were recorded. The final weight and volume of the sample were recorded from these differences. The bulk density $(\mathrm{g} / \mathrm{mL})$ was calculated as the weight of powder $(\mathrm{g})$ divided by the volume of powder $(\mathrm{mL})$ according to the Equation Number 2.

Bulk density $(\mathrm{g} / \mathrm{mL})=($ Final weight of sample/Final volume of sample $)$

\subsubsection{Gelation Characteristics}

The gelation capacity of JSPI was determined according to the method followed by [25] with a slight modification. A range of sample suspensions from $2 \%$ to $14 \%(\mathrm{w} / \mathrm{v})$ concentrations was prepared into two different solvents; distilled water and $1.0 \mathrm{M} \mathrm{NaCl}$ solution. The test tubes containing these suspensions were then heated for $1 \mathrm{~h}$ in a boiling water bath and followed by a rapid cooling under cold water tap. The tubes were further cooled for $2 \mathrm{~h}$ at $4^{\circ} \mathrm{C}$. The least gelation concentration (LGC) was determined as the minimum concentration required to form a self-supporting gel when the sample did not fall or slip from the inverted test tube.

\subsubsection{Measurement of Foam Properties}

Foaming capacity and stability of JSPI at different $\mathrm{pH}(1.5$ - 11.5) were determined according to the method described in [26]. The protein samples (2 g) were kept into $250 \mathrm{~mL}$ beakers and diluted with $100 \mathrm{~mL}$ of distilled water. The $\mathrm{pH}$ values were adjusted from 1.5 to 11.5 by using $\mathrm{HCl}$ and $\mathrm{NaOH}$. The suspensions were mixed thoroughly using magnetic stirrer and finally homogenized at $5000 \mathrm{rpm}$ for $5 \mathrm{~min}$ (WiseMix ${ }^{\mathrm{TM}}$, HG-15 D). The volume of the produced foam in each beaker was measured by measuring cylinder within no later than $30 \mathrm{~s}$. The increment of foam volume was estimated following Equation Number 3 and expressed as percent foam capacity. The foam stability of JSPI was calculated by 
Equation Number 4 from the decreased foam volume after $30 \mathrm{~min}$.

Foaming capacity $(\%)=($ Foam volume/Initial sample volume $) \times 100$

Foaming stability $(\%)=($ Foam volume after 30 minutes/Initial foam volume $) \times 100$ (4)

\subsubsection{Measurement of Emulsion Properties}

The emulsification capacity of JSPI was also determined at a range of $\mathrm{pH}$ from 1.5 to 11.5 was according to the method stated by [23] and was expressed as percent of oil emulsified per $\mathrm{g}$ of protein. A dispersion of $1 \mathrm{~g}$ isolated protein in $25 \mathrm{~mL}$ distilled water was prepared by continuous stirring at moderate speed for $30 \mathrm{~min}$ at $600 \mathrm{rpm}$. Five (5) $\mathrm{mL}$ refined groundnut oil was added, and after adjusting $\mathrm{pH}$ the mixed slurry was blended at $3000 \mathrm{rpm}$ until phase separation was seen. The emulsion capacity was estimated based on separated cream following Equation Number 5.

Emulsification capacity $(\%)=($ Cream volume $/$ Initial sample volume $) \times 100$

The emulsion stability was determined according to the method used in [27] with a slight modification. The above emulsions in different $\mathrm{pH}$ were transferred into test tubes and held at $70^{\circ} \mathrm{C}$ in a water bath for $45 \mathrm{~min}$. The tubes were then allowed to stand at room temperature for $3 \mathrm{~h}$. Percent stability was calculated from the height of the remaining emulsified layer and the original emulsified layer, according to Equation Number 6.

Emulsion stability $(\%)=($ Cream volume after $3 \mathrm{~h} /$ Initial cream volume $) \times 100(6)$

\subsection{Physicochemical Characteristics of JSPI}

\subsubsection{Particles Size Distributions}

The particle size distribution of the spray dried JSPI powder was determined according to [28] with slight modification. The experiments were carried out using a Zeta Sizer (ZEN3600, Malvern Instruments Ltd., Malvern, UK). Well dispersed samples at $4 \mathrm{mg} / 100 \mathrm{ml}(\mathrm{w} / \mathrm{v})$ concentration were used in this test. Dispersions were prepared in distilled water with gentle stirring for $60 \mathrm{~min}(400 \mathrm{rpm})$ at ambient temperature. These dispersions were kept overnight at $4^{\circ} \mathrm{C}$ for complete hydration and then diluted again with distilled water to the final concentration $(4 \mathrm{mg} / 100 \mathrm{ml}, \mathrm{w} / \mathrm{v})$. The size distribution data were obtained and analyzed by using Malvern's proprietary software version 7.01.

\subsubsection{X-Ray Diffraction (XRD) Analysis}

The X-ray diffraction (XRD) pattern of JSPI powder was measured to assess the crystalline/amorphous behavior of the isolated protein. This study was carried out on a Siemens (D501) X-ray diffractometer with CuKal radiation [29]. Diffractograms were recorded between $8^{\circ}$ and $52.15^{\circ}(2 \theta)$ at a rate of $1.20^{\circ} / \mathrm{min}(2 \theta)$ with a step size of $0.05^{\circ}(2 \theta)$. An anti-scatter slit of $0.15 \mathrm{~mm}$ and $1^{\circ}$ divergence and receiving slits were used.

\subsubsection{Scanning Electron Microscopy (SEM)}

Particle morphology of the spray dried JSPI was observed by using a scanning 
electron microscope (JEOL, JSM 6300 SEM, JEOL, Tokyo, Japan). The powder sample was directly deposited on an aluminum stub using double-sided adhesive carbon conductive tape. The entire assembly was put in a desiccator containing freshly dried silica gel for 72 hours. Then the sample was sputter-coated with a thin layer of gold. The SEM micrographs were acquired at an accelerating voltage of $15 \mathrm{kV}$.

\subsubsection{Differential Scanning Calorimetry (DSC) Method}

DSC tests were carried out to measure the calorimetric changes in spray dried JSPI and these changes were correlated to determine its denaturation temperature. The analysis was carried out by using DSC Q2000, (TA instruments, New Castle, USA) [30]. The JSPI powder was dispersed at $20 \%(\mathrm{w} / \mathrm{w})$ concentration distilled water. About $18 \pm 1 \mathrm{mg}$ of sample solution was taken in the aluminum pan and sealed hermetically. The samples were scanned from $20^{\circ} \mathrm{C}$ to $100^{\circ} \mathrm{C}$ at a heating rate of $5^{\circ} \mathrm{C} / \mathrm{min}$. The instrument was calibrated by using indium standard (fusion temperature $=156.61^{\circ} \mathrm{C}$ and fusion enthalpy $=28.67 \mathrm{~J} / \mathrm{g}$ ) $[31]$. The software associated with the instrument (TA Universal Analysis $2000^{\mathrm{TM}}$ ) was used to analyze the DSC thermograms. The extent of denaturation was determined using a change of enthalpy $(\Delta \mathrm{H})$ from $50^{\circ} \mathrm{C}$ to $95^{\circ} \mathrm{C}$.

\subsubsection{Fourier Transform Infrared (FTIR) Spectroscopy}

The FTIR spectroscopy was used in the present study to observe the conformation and secondary structural motifs of the isolated protein. The IR spectra were acquired through Perkin Elmer FTIR (Spectrum-2) instrument operated by CPU32M software. The JSPI powder was scanned within 650 to $4000 \mathrm{~cm}^{-1}$ using a triglycine sulfate (TGS) detector. A total of 8 scans at $4 \mathrm{~cm}^{-1}$ resolution were accumulated at $0.2 \mathrm{~cm} / \mathrm{sec}$ scanning speed. The JFSs flour and the separated JFSs starch were also scanned to observe the comparative spectra among those materials. The protein sample was diluted in deionized water at $1 \%$ concentration $(w / v)$ for the secondary structural quantification. The spectrum of the aqueous protein solution was acquired in the same IR conditions described above. The blank spectrum of water was subtracted from the protein spectrum. The baseline subtracted protein spectra were analyzed by using Perkin Elmer's proprietary software (Version 10.05.03), and a peak fit software Peak Fit version 4.12 (Sea Solve Software Inc. Framingham, USA). The peak Fit Software was used for quantitative analysis of the secondary structure of the protein. The original spectra (of amide region-I, $1600-1700 \mathrm{~cm}^{-1}$ ) without any smoothing were fitted with Gaussian shape and were analyzed by the local least square (LLS) algorithm. Percentage of secondary structures ( $\alpha$-helix, $\beta$-sheets, $\beta$-turns, and random coils) was estimated using Equation Number 7 [32] [33].

$$
\text { Secondary structure }(\%)=A_{\text {ind }} / A_{\text {total }} \times 100
$$

where, $A_{\text {ind }}=$ Sum of the area of individual secondary structure within amide I band.

$$
A_{\text {total }}=\text { Area of total amide I band. }
$$


The positions or locations of bands for each secondary structural element ( $\beta$-sheets, $\alpha$-helix, and $\beta$ turns) of tested proteins in $\mathrm{H}_{2} \mathrm{O}$ were considered based on the information available in the literature [12] [34]. The bands from 1620 to $1640 \mathrm{~cm}^{-1}$ and $1674 \mathrm{~cm}^{-1}$ to $1680 \mathrm{~cm}^{-1}$ were assigned to $\beta$-sheets. The bands from 1641 to $1647 \mathrm{~cm}^{-1}$ were assigned to random coil. The bands within 1648 and $1660 \mathrm{~cm}^{-1}$ were assigned to $\alpha$-helix. Similarly, the bands appearing at and in the vicinity of $1663 \mathrm{~cm}^{-1}, 1671 \mathrm{~cm}^{-1}, 1683 \mathrm{~cm}^{-1}, 1688 \mathrm{~cm}^{-1}$, and $1694 \mathrm{~cm}^{-1}$ were assigned to $\beta$ turns. The peaks between $1600 \mathrm{~cm}^{-1}-1619 \mathrm{~cm}^{-1}$ were not considered while quantifying the secondary structural features as they are known to be generated from aromatic side chains [32].

\section{Results and Discussion}

\subsection{JSPI and Its Protein Content}

According to the quantitative assessment using Micro-Kjeldahl method we found that the crude JSPI contained $76.89 \%$ protein, which is comparable to other plant based protein isolate. For example, [35] prepared tomato seeds protein isolate with $71.32 \%$ protein content, and [36] isolated rice bran protein with $60 \%$ protein content. The FTIR spectra, in this study, confirmed the separation of JFSs flour into its two principal components protein and starch (Figure 1). As shown in Figure 1(a), the flour is a mixture of high amount of starch (band region $900-1200 \mathrm{~cm}^{-1}$ ) [37] [38] and comparatively low amount of protein

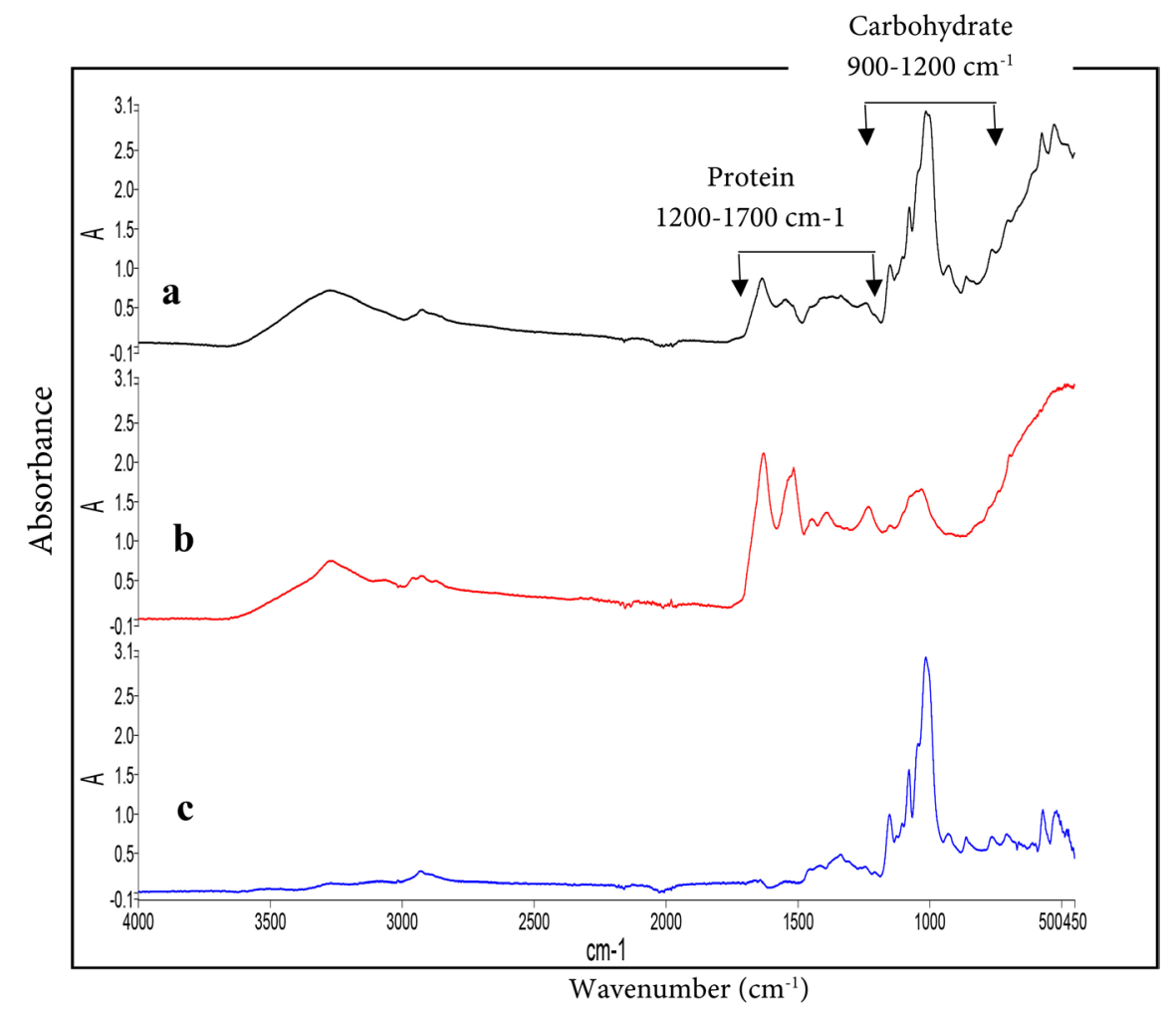

Figure 1. FTIR absorbance spectra of (a) JFSs flour; (b) Isolated JFSs protein; (c) JFSs starch after removal of protein. 
(band region $1200-1700 \mathrm{~cm}^{-1}$ ) [39] [40]. The spectra $\mathrm{b} \& \mathrm{c}$ on the figure presented the protein and starch isolated from JFSs flour.

\subsection{Functional Properties of JSPI}

\subsubsection{Protein Solubility}

The solubility of JSPI was found as $78.44 \%$. This value of solubility is comparable with the percent solubility of other proteins isolated from different sources. Reference [4] found variation in solubility of the protein isolates prepared by different drying methods, such as vacuum dried, spray dried and freeze dried lentil protein isolate showed $51 \%, 81 \%$ and $78 \%$ solubility respectively. The literature suggests that the spray dried powder possesses more amorphous particles, which provides increased solubility during rehydration [15] [41]. The percent solubility of rice bran protein concentrate ranged from $47.69 \%$ to $73 \%$ based on varieties of rice [36]. Protein isolate with higher solubility is preferred for direct consumption as well as utilization as a food ingredient. Therefore, using a spray dryer for commercial production of JSPI is recommended to produce the concentrated protein with higher solubility.

\subsubsection{Water Holding Capacity}

The water holding capacity of the JSPI was $2.89 \mathrm{~mL} \mathrm{H}_{2} \mathrm{O} / \mathrm{g}$ protein, which is higher than the water holding capacity of cowpea protein, $2.20 \mathrm{~mL} \mathrm{H}_{2} 0 / \mathrm{g}$ [42], but lower than that of the wheat bran protein, $4.20 \mathrm{~mL} \mathrm{H}_{2} 0 / \mathrm{g}$ [2]. High water holding capacity of proteins helps to reduce moisture loss from bakery goods and maintains freshness and moist mouth feel of the products. The obtained values indicate that the JSPI powder needs to be mixed with a portion of wheat protein to have adequate swelling and water retention during food preparation.

\subsubsection{Oil Holding Capacity}

The oil-holding capacity of JSPI was $1.57 \mathrm{~mL}$ oil/g protein, which is slightly lower compared to wheat bran protein $1.70 \mathrm{~mL} / \mathrm{g}$ [2]. Higher oil holding capacity is advantageous for oily food like sausages, mayonnaise, and salad dressing. Therefore, utilization of JSPI combined with a protein of higher oil holding capacity is preferred for such a food.

\subsubsection{Bulk Density}

This is an important parameter of a powder or a mix of powders to determine the packaging requirement of the product. The bulk density of JSPI was 0.67 $\mathrm{g} / \mathrm{mL}$, which is less compared to the bulk density of casein $0.89 \mathrm{~g} / \mathrm{mL}$ [35]. Low bulk density is advantageous for the formulation of weaning foods regarding packaging and transportation [43].

\subsubsection{Gelation Characteristics}

In the process of gel formation, about $6 \%$ JSPI in $1.0 \mathrm{M} \mathrm{NaCl}$ solution initiated forming a gel; however, this gel was not consistent enough to withstand the gravity force at the inverted position of the container. At least $12 \%(\mathrm{w} / \mathrm{v})$ JSPI 
concentration in that solution was required to make a firm gel (Table 1). The protein did not form a gel in pure water. Reference [4] found the least gelling concentration of lentil protein isolate was $14 \%$ in a phosphate buffer of $\mathrm{pH}$ 7.0. The lower least gelation concentration implies the greater gelling capacity of the protein [44].

\subsubsection{Foaming Properties}

The foaming capacity (FC) of isolated jackfruit seeds protein was $\mathrm{pH}$-dependent. As shown in Figure 2, the alkaline solution resulted in better foam formation. The FC increased from the lowest value of $6 \%$ at pH 5.5 to $42 \%, 25 \%, 46 \%, 58 \%$, and $74 \%$ at $\mathrm{pH} 1.5,3.5,7.5,9.5$, and 11.5 , respectively. The findings comply with the previous observation that the alkaline solution is favorable for the protein solubility and foaming capacity [45]. This trend could be due to the fact that the variation of $\mathrm{pH}$ affects the net charge and electrostatic balance of the protein solution. The solubility of protein tends to be minimum near the isoelectric point

Table 1. Gelation capacity (GC) of jackfruit seeds protein isolate in water and $\mathrm{NaCl}$ solution.

\begin{tabular}{ccc}
\hline Isolated proteins (\%) & GC in $\mathrm{H}_{2} \mathrm{O}$ & GC in $1.0 \mathrm{M} \mathrm{NaCl}$ solution \\
\hline 2 & - & - \\
4 & - & - \\
6 & - & + \\
8 & - & ++ \\
10 & - & ++ \\
12 & - & +++ \\
14 & - & +++ \\
\hline
\end{tabular}

Note: Symbols: - no gel; + weak gel; ++ strong gel; +++ very strong gel.

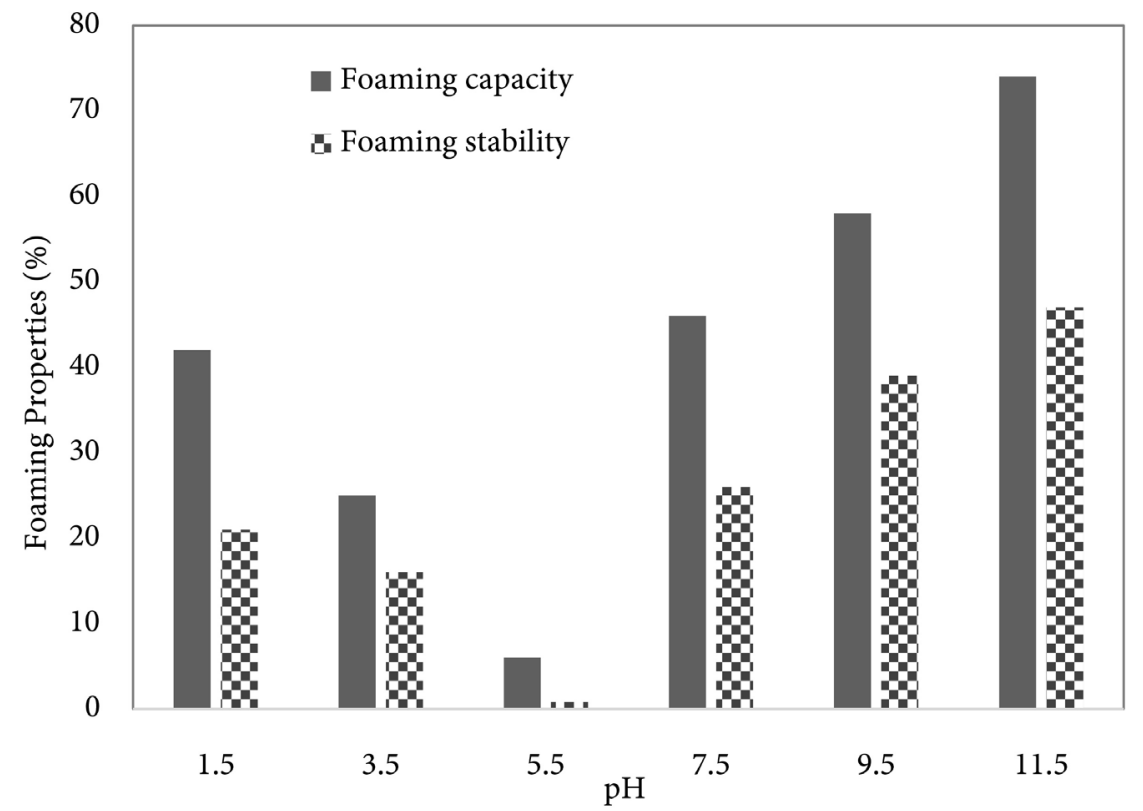

Figure 2. Effect of $\mathrm{pH}$ on the foaming capacity and foaming stability of jackfruit seeds protein isolate (JSPI). 
(IP) because of negligible or zero net charge. The IPs of the most plant proteins are reportedly fallen between 4 and 5 [21]. The higher FC at pH 11.5 was likely due to the increased net charges on the protein molecules, which weakened the hydrophobic interactions and increased the flexibility of the protein [2]. These phenomena allowed the protein to diffuse more rapidly to the air-water interface to encapsulate air particles and then enhanced the foam formation.

The foaming stability (FS) requires the formation of a thick, cohesive, and viscoelastic film around each gas bubble [46]. Isolated jackfruit seeds protein showed poor foam stability at $\mathrm{pH} 5.5(0.83 \%)$. On both sides of $\mathrm{pH} 5.5$, the foaming stability gradually increased and reached its maximum value of $47 \%$ at $\mathrm{pH}$ 11.5. The solutions with $\mathrm{pH} 7.5,9.5$, and 1.5 showed about $26 \%, 39 \%$, and $21 \%$ FSs, respectively (Figure 2). The previous researches also observed a considerable effect of $\mathrm{pH}$ on the stability of foams [35] [47]. The improvement of FS in the alkaline $\mathrm{pH}$ is likely due to increased solubility and surface activity of the soluble protein.

\subsubsection{Emulsifying Properties}

The $\mathrm{pH}$ of solution has a significant effect on emulsion properties also. As shown in Figure 3, JSPI had a minimum emulsion capacity (EC) (2\%) at pH 5.5, which increased on either side of this $\mathrm{pH}$. The $\mathrm{pH} 11.5$ of the solution showed the highest EC of $63 \%$, which was followed by the $\mathrm{pH}$ of 9.5 and 7.5 , with EC values of $56 \%$ and $25 \%$, respectively. The observed results suggest that the alkaline $\mathrm{pH}$ improved the emulsion capacity from the acidic one. Dependence of emulsion capacity on $\mathrm{pH}$ was expected, as the emulsion capacity of a protein is known to depend on the hydrophilic-lipophilic balance and electrostatic repulsion at the isoelectric point. The JSPI had minimum emulsion stability at $\mathrm{pH} 5.5$ $(0.43 \%$ after $3 \mathrm{~h})$ and reached the maximum value of $52 \%$ at $\mathrm{pH} 11.5$ (Figure 3 ).

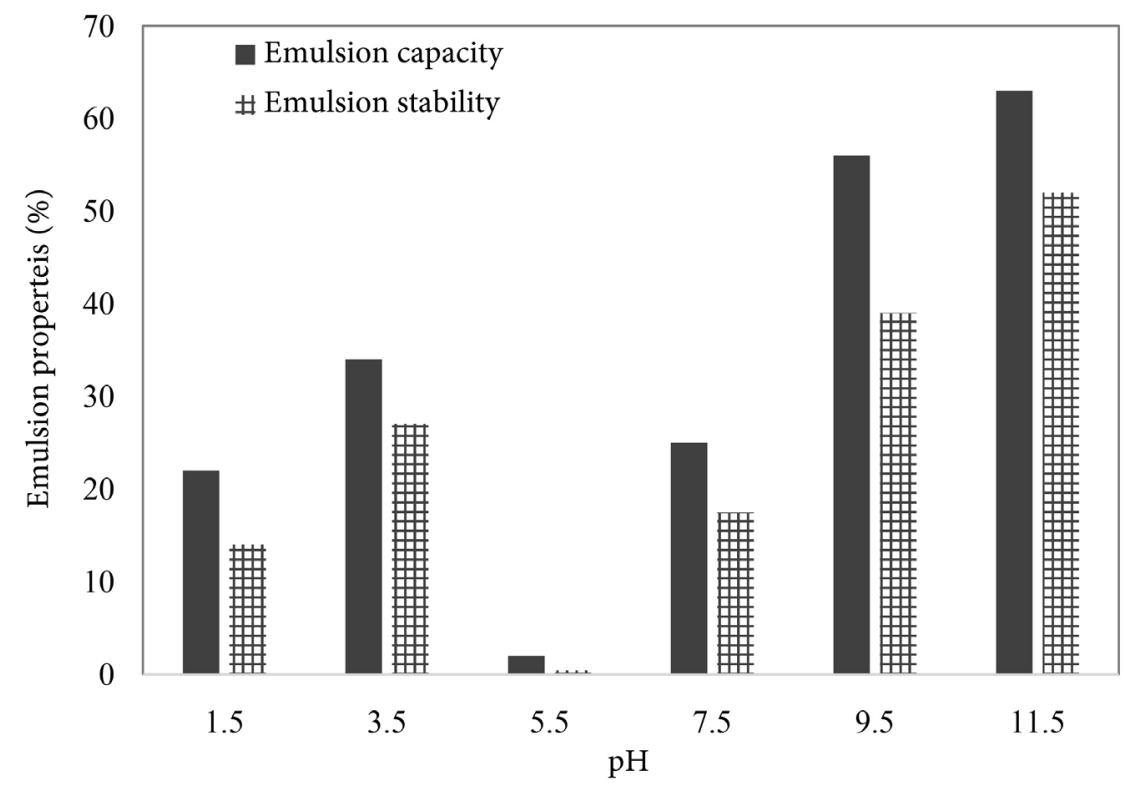

Figure 3. Effect of $\mathrm{pH}$ on the emulsion properties of JSPI. 
It is reported that various factors including $\mathrm{pH}$, net charge, interfacial tension, viscosity, and protein conformation could affect the values of ES [48].

\subsection{Physicochemical Properties of JSPI}

\subsubsection{Particle Size and Size Distributions}

The particle size and size distribution curve of the spray dried JSPI are presented in Figure 4. The curve suggests that about $75.0 \%$ (by volume) particles ranged from 100 to $1000 \mathrm{~nm}$ and around $23.0 \%$ of the particles were smaller than 100 $\mathrm{nm}$. About 2\% particles' diameter was larger than $1000 \mathrm{~nm}$. The variation of size found in this curve reflects the disparity of morphological image (Figure 6). This observation consents to the previous finding that the micro particulation process of bio particles delivers finer to comparatively larger particles [49].

\subsubsection{Crystallinity of JSPI}

The XRD diffractogram is presented in Figure 5. Absence of any sharp peak Size Distribution by Volume

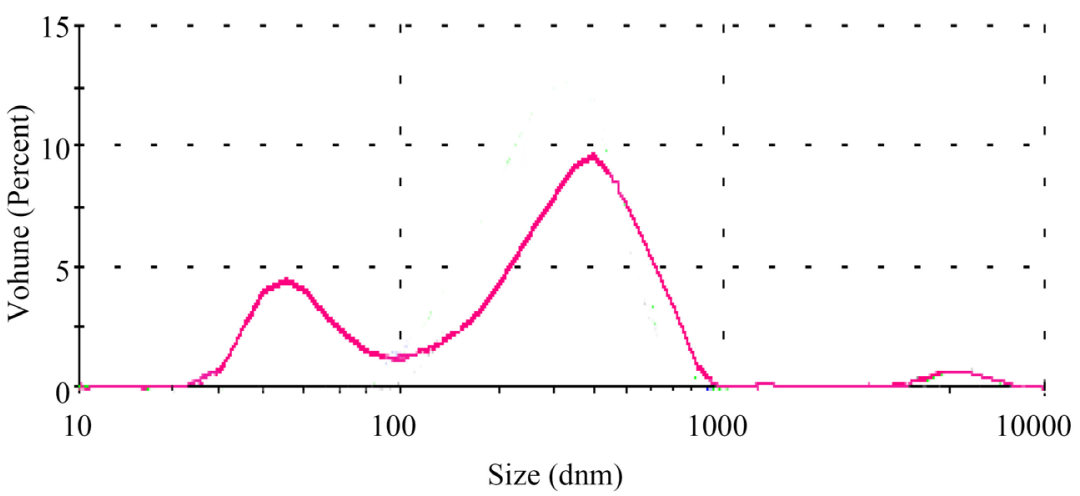

Spray dried JSPI

Figure 4. Particle size distribution curve of spray dried JSPI.

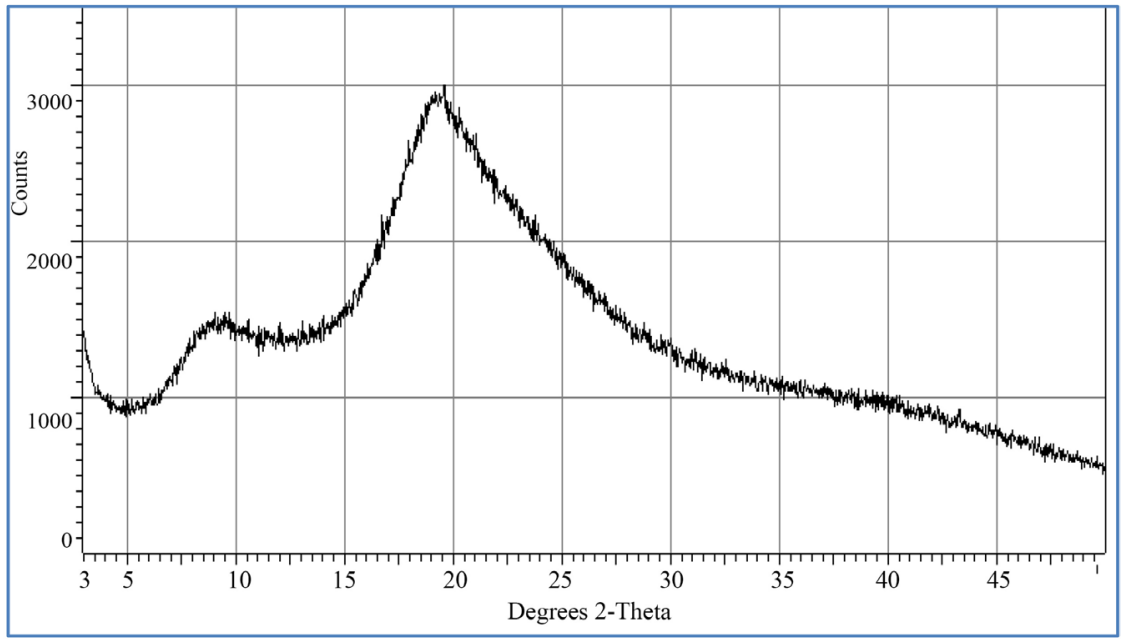

Figure 5. X-ray diffraction pattern of spray dried JSPI. 
suggests that the spray-dried JSPI particles were amorphous in nature. However, two broad peaks were found at 9.0 and 19.0 degrees $2 \theta$ on the JSPI diffractogram. Reference [50] observed three peaks (at 8.5, 19.5 and 24.5 degrees $2 \theta$ ) on the soy protein isolate diffractogram and reference [4] reported two broad peaks (at 8.5 and 24.5 degrees $2 \theta$ ) on the lentil protein isolate diffractogram. It is reported that the powder form of protein normally possesses the amorphous behavior [29] [51].

\subsubsection{Surface Morphology}

The SEM micrographs of JSPI powder presented in two images with two different magnifications appear varying sizes of particles (Figure 6). The surface of the spray-dried protein isolate produced more or less spherical appearance with dimples and surface folds. Higher magnification micrograph shows the smooth-surfaced hollow particles, although they possess indented surface. The low diffusion rate of the moisture from the aqueous droplets containing skin-forming solids is the primary reason for the formation of hollow particles in spray dried particles [52].

\subsubsection{DSC Thermograph for Thermal Denaturation of JSPI}

According to the DSC thermogram (Figure 7), about $1.810 \mathrm{~J} / \mathrm{g}$ energy required to denature the jackfruit protein isolate. The endothermic peak produced by the thermal scanning from $20^{\circ} \mathrm{C}$ to $100^{\circ} \mathrm{C}$ suggests that the denaturation temperature (Td) of JSPI was about $77.83^{\circ} \mathrm{C}$. The denaturation temperature of the spray-dried lentil protein isolate was reported as $123.6^{\circ} \mathrm{C}$ [4]. They concluded that the $\mathrm{Td}$ value can be changed with the variation of crops or with the verities of same crop. Reference [14] suggested that the variation of Td can be due to the variation of concentration of protein in the solution. They demonstrated that the $\mathrm{Td}$ values vary from $75^{\circ} \mathrm{C}$ to $80^{\circ} \mathrm{C}$ with the variation of concentration of whey protein isolate from $20 \%$ to $40 \%$.

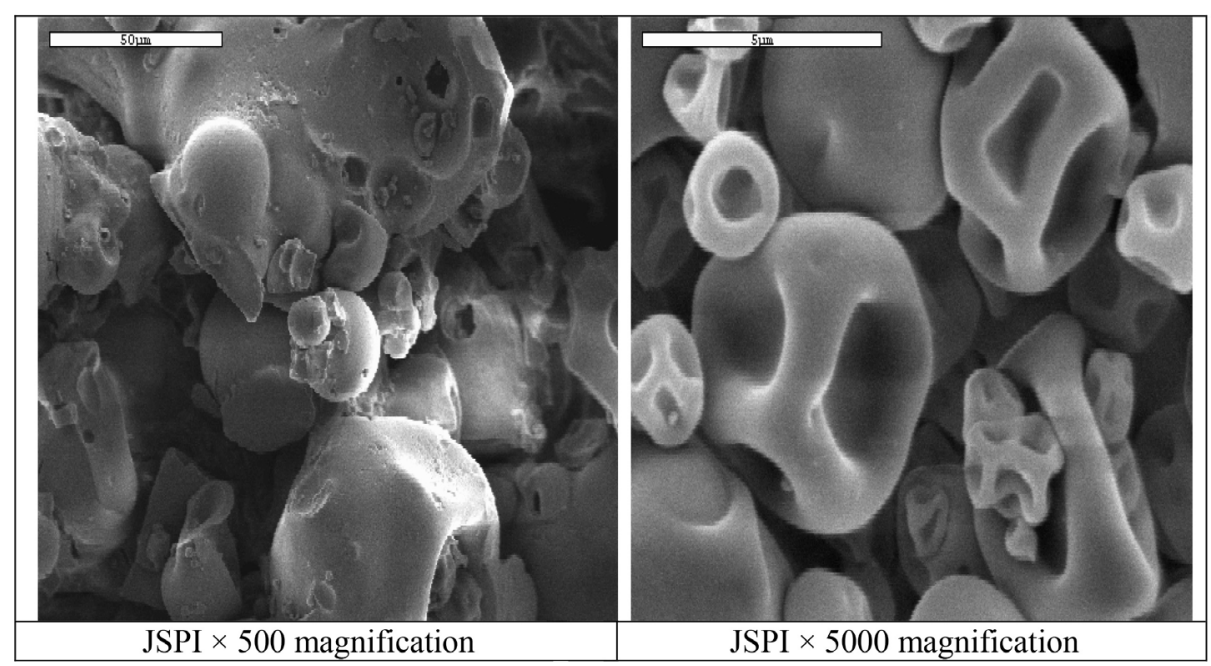

Figure 6. Scanning electron microscope (SEM) pictures of JSPI powders with two different magnifications. 


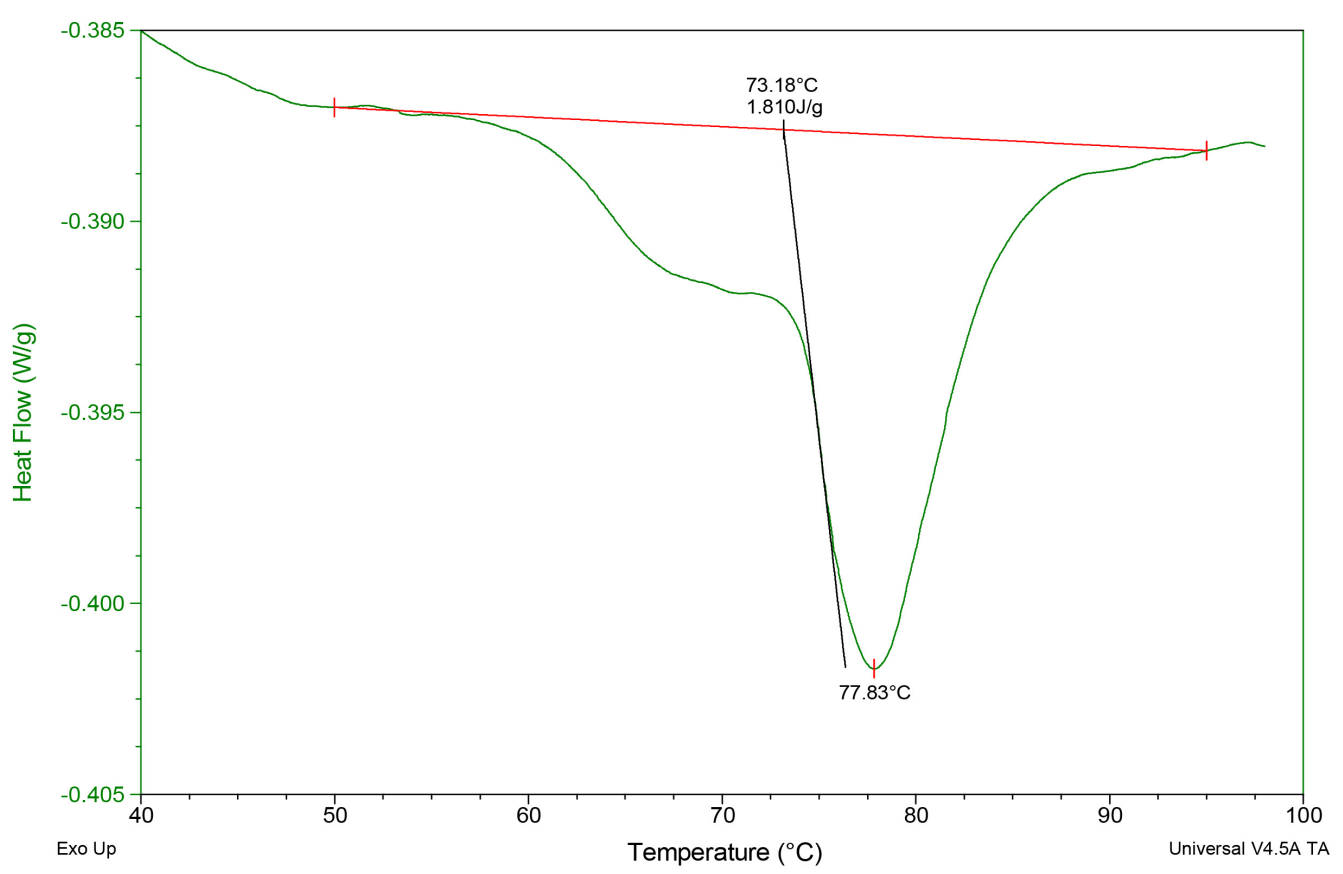

Figure 7. DSC thermogram of spray dried JSPI (thermal scanning from $20^{\circ} \mathrm{C}$ to $100^{\circ} \mathrm{C}$ ).

\subsubsection{Secondary Structural Properties of JSPI}

A cut off portion of the amide region-I $\left(1600-1700 \mathrm{~cm}^{-1}\right)$ from the original absorption spectrum and its fitted spectra are presented in Figure 8. The amide-I region was selected for secondary structural quantification because of its very high signal to noise ratio [53] [54]. As seen in the figure, there were nine bands (excluding side chain) produced for the best fitting of the amide-I region with an $\mathrm{r}^{2}$ value of 0.97 . The quantification tools of the assigned bands estimated that the JFSs protein contained $50.28 \% \beta$-sheet, $21.71 \% \alpha$-helix, $8.86 \% \beta$-turn, and $19.15 \%$ unordered structure. The result advised that the $\beta$-sheet is the dominant secondary structure of JFSs protein.

\section{Conclusion}

The protein fraction of the jackfruit seeds was successfully isolated through $\mathrm{pH}$ treatment, centrifugation and spray drying process. About $77 \%$ protein was found to present in the crude JSPI. The isolated protein showed acceptable physicochemical and functional characteristics for the plan of using JSPI in food formulations. For example, it possesses good solubility, amorphous nature, moderate bulk density and an attractive gel-forming ability. Variation of $\mathrm{pH}$ in the solution imposed a significant effect on foaming and emulsion properties. Both the foaming capacity and emulsion capacity reached their maximum values at a $\mathrm{pH}$ of 11.5. The protein isolate possessed adequate water holding capacity, oil holding capacity, and almost $75 \%$ of the particles fall in a similar size distribution range. The JFSs protein contained 50.28\% $\beta$-sheet, $21.71 \% \alpha$-helix, 8.86\% $\beta$-turn, and $19.15 \%$ unordered properties in the secondary structure. Based on the observed functional and physicochemical features, the JSPI is expected to use 


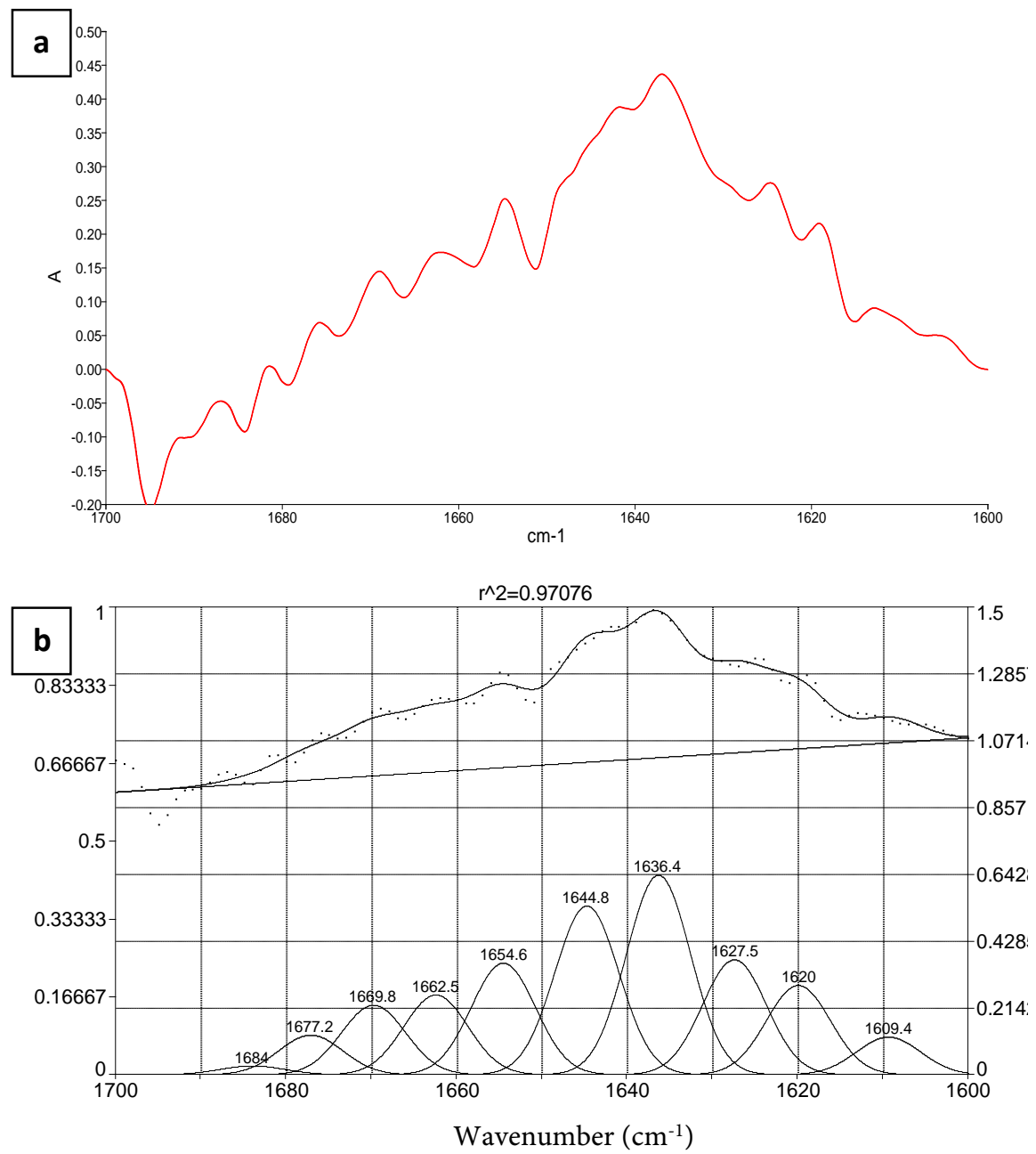

Figure 8. (a) Absorbance (b) fitted spectra of the JFSs protein isolate in the amide-I region.

as a supplementary ingredient in the food formulations. However, more studies are required to recommend the optimum level of fortification of this protein in foods.

\section{Acknowledgements}

The authors gratefully acknowledge the Ministry of Education of Bangladesh for financing the project.

\section{Conflicts of Interest}

The authors declare no conflicts of interest regarding the publication of this paper.

\section{References}

[1] Houde, M., Khodaei, N., Benkerroum, N. and Karboune, S. (2018) Barley Protein Concentrates: Extraction, Structural and Functional Properties. Food Chemistry, 254, 367-376. https://doi.org/10.1016/j.foodchem.2018.01.156 
[2] Idris, W.H., Babiker, E.E. and Tinay, A.H.E. (2003) Fractionation, Solubility and Functional Properties of Wheat Bran Proteins as Influenced by $\mathrm{pH}$ and/or Salt Concentration. Molecular Nutrition, Food Research, 47, 425-429. https://doi.org/10.1002/food.200390094

[3] Kaushik, P., Dowling, K., McKnight, S., Barrow, C., Wang, B. and Adhikari, B. (2016) Preparation, Characterization and Functional Properties of Flaxseed Protein Isolate. Food Chemistry, 197, 212-220. https://doi.org/10.1016/j.foodchem.2015.09.106

[4] Joshi, M., Adhikari, B., Aldred, P., Panozzo, J.F. and Kasapis, S. (2011) Physicochemical and Functional Properties of Lentil Protein Isolates Prepared by Different Drying Methods. Food Chemistry, 129, 1513-1522.

https://doi.org/10.1016/j.foodchem.2011.05.131

[5] Miah, M.Y., Bhattacharjee, S., Sultana, A., Bhowmik, S., Sarker, A.K., Paul, S.C., Islam, M.S. and Zaman, A. (2017) Evaluation of Amino Acid Profile of Jackfruit (Artocarpus heterophyllus) Seed and Its Utilization for Development of Protein Enriched Supplementary Food. Journal of Noakhali Science and Technology University, 1, 77-84.

[6] Ocloo, F.C.K., Bansa, D., Boatin, R., Adom, T. and Agbemavor, W.S. (2010) Physico-Chemical, Functional and Pasting Characteristics of Flour Produced from Jackfruits (Artocarpus heterophyllus Lam.) Seeds. Agriculture and Biology Journal of North America, 1, 903-908. https://doi.org/10.5251/abjna.2010.1.5.903.908

[7] BBS (2016) Yearbook of Agricultural Statistics of Bangladesh. Planning Division, Ministry of Planning, Peoples Republic of Bangladesh, Dhaka.

[8] Kinsella, J.E. (1979) Functional Properties of Soy Proteins. Journal of the American Oil Chemists' Society, 56, 242-249. https://doi.org/10.1007/BF02671468

[9] Mcwatters, K.H. and Cherry, J.P. (1977) Emulsification, Foaming and Protein Solubility Properties of Defatted Soybean, Peanut, Field Pea and Pecan Flours. Journal of Food Science, 42, 1444-1447. https://doi.org/10.1111/j.1365-2621.1977.tb08395.x

[10] Zayas, J.F. and Lin, C.S. (1989) Emulsifying Properties of Corn Germ Proteins. Cereal Chemistry, 66, 263-267.

[11] Haque, M.A., Aldred, P., Chen, J. and Adhikari, B. (2015). Denaturation and Physical Characteristics of Spray Dried Whey Protein Isolate Powders Produced in the Presence and Absence of Lactose, Trehalose and Polysorbate-80. Drying Technolo$g y$, 33, 1243-1254. https://doi.org/10.1080/07373937.2015.1023311

[12] Ji, Y.-Y. and Li, Y.-Q. (2010) The Role of Secondary Structure in Protein Structure Selection. The European Physical Journal, Soft Matter, 32, 103-107.

https://doi.org/10.1140/epje/i2010-10591-5

[13] Haque, M.A., Aldred, P., Chen, J., Barrow, C. and Adhikari, B. (2014) Drying and Denaturation Characteristics of $\alpha$-Lactalbumin, $\beta$-Lactoglobulin and Bovine Serum Albumin in a Convective Drying Process. Journal of Agricultural and Food Chemistry, 62, 4695-4706. https://doi.org/10.1021/jf405603c

[14] Anandharamakrishnan, C., Rielly, C.D. and Stapley, A.G.F. (2007) Effects of Process Variables on the Denaturation of Whey Proteins during Spray Drying. Drying Technology, 25, 799-807. https://doi.org/10.1080/07373930701370175

[15] Farrell Jr., H.M., Wickham, E.D., Unruh, J.J., Qi, P.X. and Hoagland, P.D. (2001) Secondary Structural Studies of Bovine Caseins: Temperature Dependence of $\beta$-Casein Structure as Analyzed by Circular Dichroism and FTIR Spectroscopy and Correlation with Micellization. Food Hydrocolloids, 15, 341-354.

https://doi.org/10.1016/S0268-005X(01)00080-7 
[16] Abdul-Fattah, A.M., Kalonia, D.S. and Pikal, M.J. (2007) The Challenge of Drying Method Selection for Protein Pharmaceuticals: Product Quality Implications. Journal of Pharmaceutical Sciences, 96, 1886-1915. https://doi.org/10.1002/jps.20842

[17] Chavez, B.E. and Ledeboer, A.M. (2007) Drying of Probiotics: Optimization of Formulation and Process to Enhance Storage Survival. Drying Technology, 25, 1193-1201. https://doi.org/10.1080/07373930701438576

[18] Resendiz-Vazquez, J.A., Ulloa, J.A., Urías-Silvas, J.E., Bautista-Rosales, P.U., Ramírez-Ramírez, J.C., Rosas-Ulloa, P. and González-Torres, L. (2017) Effect of High-Intensity Ultrasound on the Technofunctional Properties and Structure of Jackfruit (Artocarpus heterophyllus) Seed Protein Isolate. Ultrasonics Sonochemistry, 37, 436-444. https://doi.org/10.1016/j.ultsonch.2017.01.042

[19] Resendiz-Vazquez, J.A., Urías-Silvas, J.E., Ulloa, J.A., Bautista-Rosales, P.U. and Ramírez-Ramírez, J.C. (2019) Effect of Ultrasound-Assisted Enzymolysis on Jackfruit (Artocarpus heterophyllus) Seed Proteins: Structural Characteristics, Technofunctional Properties and the Correlation to Enzymolysis. Journal of Food Processing \& Technology, 10, 796.

[20] Chowdhury, A.R., Bhattacharyya, A.K. and Chattopadhyay, P. (2014) Functional and Nutritional Characterization of Jackfruit Seed Flour under Different Drying Conditions. Proceedings of the International Conference of Food Properties, Kuala Lumpur, Malaysia, January 2014, 24-26.

[21] Ulloa, J.A., Barbosa, M.C.V., Resendiz-Vazquez, J.A., Rosas-Ulloa, P., Ramírez-Ramírez, J.C., Carrillo, Y.S. and Torres, L.G. (2017) Production, Physico-Chemical and Functional Characterization of a Protein Isolate from Jackfruit (Artocarpus heterophyllus) Seeds. Cyta-Journal of Food, 15, 497-507. https://doi.org/10.1080/19476337.2017.1301554

[22] AOAC (1984) Official Methods of Analysis. 14th Edition, Association of Official Agricultural Chemists, Washington DC.

[23] Beuchat, L.R., Cherry, J.P. and Quinn, M.R. (1975) Physicochemical Properties of Peanut Flour as Affected by Proteolysis. Journal of Agricultural and Food Chemistry, 23, 616-620. https://doi.org/10.1021/jf60200a045

[24] Carcea, B.M. (1986) Functional Properties of Drum Dried Chickpea (Cicer arictinum L). Journal of Food Science, 51, 1518-1526. https://doi.org/10.1111/j.1365-2621.1986.tb13849.x

[25] Coffman, C. and Gracia, V.V. (1977) Functional Properties and Amino Acid Content of Protein Isolate from Mug Bean Flour. Journal of Food Science and Technology, 12, 473-478. https://doi.org/10.1111/j.1365-2621.1977.tb00132.x

[26] Aruna, V. and Prakash, V. (1993) Functional Properties of the Total Proteins of Sunflower (Helianthus annuus L.) Seeds-Effect of Physical and Chemical Treatments. Journal of Agricultural and Food Chemistry, 41, 18-23.

https://doi.org/10.1021/jf00025a005

[27] Pearce, K.N. and Kinsella, J.E. (1978) Emulsifying Properties Of Proteins: Evaluation of a Turbidimetric Technique. Journal of Agricultural and Food Chemistry, 26, 716-723. https://doi.org/10.1021/jf60217a041

[28] Gunasekaran, S., Ko, S. and Xiao, L. (2007) Use of Whey Proteins for Encapsulation and Controlled Delivery Applications. Journal of Food Engineering, 83, 31-40. https://doi.org/10.1016/j.jfoodeng.2006.11.001

[29] Jayasundera, M., Adhikari, B., Howes, T. and Aldred, P. (2011) Surface Protein Coverage and Its Implications on Spray-Drying of Model Sugar-Rich Foods: Solubility, Powder Production and Characterisation. Food Chemistry, 128, 1003-1016. 
https://doi.org/10.1016/j.foodchem.2011.04.006

[30] Boye, J.I. and Alli, I. (2000) Thermal Denaturation of Mixtures of $\alpha$-Lactalbumin and $\beta$-Lactoglobulin: A Differential Scanning Calorimetric Study. Food Research International, 33, 673-682. https://doi.org/10.1016/S0963-9969(00)00112-5

[31] Archer, D.G. (2003) Enthalpy of Fusion of Indium: A Certified Reference Material for Differential Scanning Calorimetry. Journal of Chemical \& Engineering Data, 48, 1157-1163. https://doi.org/10.1021/je030112g

[32] Ngarize, S., Herman, H., Adams, A. and Howell, N. (2004) Comparison of Changes in the Secondary Structure of Unheated, Heated, and High-Pressure-Treated $\beta$-Lactoglobulin and Ovalbumin Proteins Using Fourier Transform Raman Spectroscopy and Self-Deconvolution. Journal of Agricultural and Food Chemistry, 52, 6470-6477. https://doi.org/10.1021/jf030649y

[33] Haque, M.A., Aldred, P., Chen, J. and Adhikari, B. (2015) Drying and Denaturation Characteristics of Whey Protein Isolate in the Presence of Lactose and Trehalose. Food Chemistry, 177, 8-16. https://doi.org/10.1016/j.foodchem.2014.12.064

[34] Kong, J. and Yu, S. (2007) Fourier Transforms Infrared Spectroscopic Analysis of Protein Secondary Structures. Acta Biochimica et Biophysica Sinica, 39, 549-559. https://doi.org/10.1111/j.1745-7270.2007.00320.x

[35] Sogi, D.S., Garg, S.K. and Bawa, A.S. (2002) Functional Properties of Seeds Meals and Protein Concentrates from Tomato Processing Waste. Journal of Food Science, 67, 2997-3001. https://doi.org/10.1111/j.1365-2621.2002.tb08850.x

[36] Chandi, G.K. and Sogi, D.S. (2007) Functional Properties of Rice Bran Protein Concentrate. Journal of Food Engineering, 79, 592-597. https://doi.org/10.1016/j.jfoodeng.2006.02.018

[37] Naumann, D. (2000) FT-Infrared and FT-Raman Spectroscopy in Biomedical Research. In: Gremlich, H.U. and Yan, B., Eds., Infrared and Raman Spectroscopy of Biological Materials, Marcel Dekker, Inc., Basel, 323-377.

[38] Grube, M., Bekers, M., Upite, D. and Kaminska, E. (2002) Infrared Spectra of Some Fructans. Spectroscopy, 16, 289-296. https://doi.org/10.1155/2002/637587

[39] Susi, H. and Byler, D.M. (1986) Resolution-Enhanced Fourier Transform Infrared Spectroscopy of Enzymes. Methods in Enzymology, 130, 290-311.

https://doi.org/10.1016/0076-6879(86)30015-6

[40] Surewicz, W.K. and Mantsch, H.H. (1988) New Insight into Protein Secondary Structure from Resolution-Enhanced Infrared Spectra. Biochimica et Biophysica Acta, 952, 115-130. https://doi.org/10.1016/0167-4838(88)90107-0

[41] Chiou, D., Langrish, T. A. G. and Braham, R. (2008) Partial Crystallization Behavior during Spray Drying: Simulations and Experiments. Drying Technology, 26, 27-38. https://doi.org/10.1080/07373930701781181

[42] Ragab, D.M., Babiker, E.E. and Eltinay, A.H. ( 2004) Fractionation, Solubility and Functional Properties of Cowpea (Vigna unguiculata) Proteins as Affected by $\mathrm{pH}$ and/or Salt Concentration. Food Chemistry, 84, 207-212. https://doi.org/10.1016/S0308-8146(03)00203-6

[43] Onimawo, I.A. and Egbekun, N.M. (1998) Comprehensive Food Science and Nutrition. Ambik Publishers, Benin City, 103-220.

[44] Kaur, M. and Singh, N. (2007) Characterization of Protein Isolates from Different Indian Chickpea (Cicer arietinum L.) Cultivars. Food Chemistry, 102, 366-374. https://doi.org/10.1016/j.foodchem.2006.05.029

[45] N-Nadozie, E.F., Kelechi, A.J. and Deborah, O. (2015) Effects $\mathrm{pH}$ and $\mathrm{NaCl}$ on the 
Protein Solubility, Emulsifying and Foaming Properties of Germinated and Ungerminated Melon (Colocynthis citrullus) Seeds Flour. International Journal of Food Science and Nutrition, 4, 173-177. https://doi.org/10.11648/j.ijnfs.20150402.18

[46] Damodaran, S. (1990) Interfaces, Protein Films and Foams. Advances in Food Nutrition Research, 34, 1-79. https://doi.org/10.1016/S1043-4526(08)60006-6

[47] Meuser, F., Busch K, G., Fuhrmeister, H. and Rubach, K. (2001) Foam Forming Capacity of Substances Present in Rye. Cereal Chemistry, 78, 50-54. https://doi.org/10.1094/CCHEM.2001.78.1.50

[48] Hung, S.C. and Zayas, J.F. (1991) Emulsifying Capacity and Emulsion Stability of Milk Proteins and Corn Germ Protein Flour. Journal of Food Science, 56, 1216-1223. https://doi.org/10.1111/j.1365-2621.1991.tb04737.x

[49] Dissanayake, M., Liyanaarachchi, S. and Vasiljevic, T. (2012) Functional Properties of Whey Proteins Microparticulated at Low pH. Journal of Dairy Science, 95, 1667-1679. https://doi.org/10.3168/jds.2011-4823

[50] Wang, Q., Du, Y., Hu, X., Yang, J., Fan, L. and Feng, T. (2006) Preparation of Alginate/Soy Protein Isolate Blend Fibers through a Novel Coagulating Bath. Journal of Applied Polymer Science, 101, 425-431. https://doi.org/10.1002/app.22369

[51] Sharma, V.K. and Kalonia, D.S. (2004) Effect of Vacuum Drying on Protein-Mannitol Interactions: The Physical State of Mannitol and Protein Structure in the Dried State. American Association of Pharmaceutical Scientists, and Technology, 5, 1-12. https://doi.org/10.1007/BF02830578

[52] Hassan, H.M. and Mumford, C.J. (1993) Mechanisms of Drying of Skin-Forming Materials. I. Droplets of Materials Which Gelatinised at High Temperature. Drying Technology, 11, 1713-1750. https://doi.org/10.1080/07373939308916925

[53] Fu, F., Deoliveira, D.B., Trumble, W.R., Sarkar, H.K. and Singh, B.R. (1994) Secondary Structure Estimation of Proteins Using the Amide III Region of Fourier Transform Infrared Spectroscopy: Application to Analyze Calcium Binding-Induced Structural Changes in Calsequestrin. Applied Spectroscopy, 48, 1432-1441. https://doi.org/10.1366/0003702944028065

[54] van de Weert, M., Haris, P.I., Hennink, W.E. and Crommelin, D.J.A. (2001) Fourier Transform Infrared Spectrometric Analysis of Protein Conformation: Effect of Sampling Method and Stress Factors. Analytical Biochemistry, 297, 160-169. https://doi.org/10.1006/abio.2001.5337 


\section{Abbreviations Used}

JSPI = Jackfruit seeds protein isolate;

$\mathrm{AOAC}=$ Association of Official Analytical Chemists;

FTIR = Fourier-transform infrared spectroscopy;

$\mathrm{FC}=$ Foaming capacity;

FS = Foaming stability;

$\mathrm{EC}=$ Emulsion capacity;

$\mathrm{ES}=$ Emulsion stability;

$\mathrm{GC}=$ Gelation concentration;

LGC $=$ The Least gelation concentration;

LLS $=$ Local least square;

TGS = Triglycine sulfate;

JFSs $=$ Jackfruit seeds . 